\title{
A filiação divina como cumprimento das antigas promessas e a nova e eterna aliança de Deus com os homens
}

\author{
Orientador: Prof. Waldecir Gonzaga \\ Pesquisador: Pedro da Costa Pereira \\ Fonte: $\mathrm{CNPq}$
}

\section{Introdução}

A grande novidade do Evangelho de João é a revelação de que, pela fé em Cristo, o homem pode se tornar filho de Deus (Jo 1,12), passar para a vida eterna (Jo 3,15-16.36; 6,40.47), nascer de novo (Jo 3,7). Isso significa dizer que, segundo o Quarto Evangelho, a fé em Cristo foi o meio escolhido por Deus para gerar novos filhos para si, para dar vida eterna aos homens. Passando a crer em Cristo, o homem é feito filho de Deus, ele passa para a vida eterna, e, desse modo, nasce de novo, pois nasce para a vida que não tinha antes de crer em Cristo. Nascer de novo é nascer para a vida eterna, é ser feito filho de Deus. A vida eterna e ser filho de Deus não são duas coisas distintas, mas o mesmo. A vida eterna "é" ser filho de Deus: ser filho de Deus "é" a vida eterna.

Dando vida eterna aos homens, ou seja, tornando-os seus filhos e, assim, salvando-os, santificando-os, Deus cumpriu antigas promessas feitas por Ele no Antigo Testamento (AT). Ser filho de Deus é a "nova" (Jr 31,31) e "eterna aliança" (Is 61,80; Jr 32,40; Br 2,35; Ez 16,60) e o "novo espírito" (Ez 36,26) outrora prometidos. É passando a crer em Cristo que o homem entra em aliança com Deus e recebe o seu Espírito Eterno, é feito seu filho. O "novo espírito", anteriormente prometido, é o espírito de filho de Deus, é ser filho de Deus, é a vida eterna. Concedida graciosamente mediante a fé em Cristo (Jo 1,12), a filiação divina não é um elemento da nova aliança, mas a nova aliança mesma. Todas essas relações, contudo, são ignoradas sempre que se afirma que todo homem quando vem ao mundo já é filho de Deus. Com isso, o assombro da mensagem central de João - Cristo veio ao mundo para que, pela fé nele, os 
homens fossem feitos filhos de Deus, recebessem a vida eterna - passa despercebido. E, igualmente, fica encobertos os termos da nova aliança. Por isso, urge pôr em evidência o conteúdo original da mensagem evangélica.

\section{Objetivos}

O objetivo da pesquisa é apresentar os sentidos essenciais que se dão pela fé em Cristo e articulá-los numa visão de conjunto à luz dos textos do Novo e do Antigo Testamentos. Em outras palavras, demonstrar como, a partir da fé em Cristo, diversos conceitos se articulam e possuem um mesmo significado; e, assim, tornar claro os significados de passar a crer em Cristo como "o mesmo": ser feito filho de Deus, receber a vida eterna, nascer de novo, receber um novo espírito (o espírito de filho de Deus), entrar em aliança com Deus, entrar no Reino de Deus. 